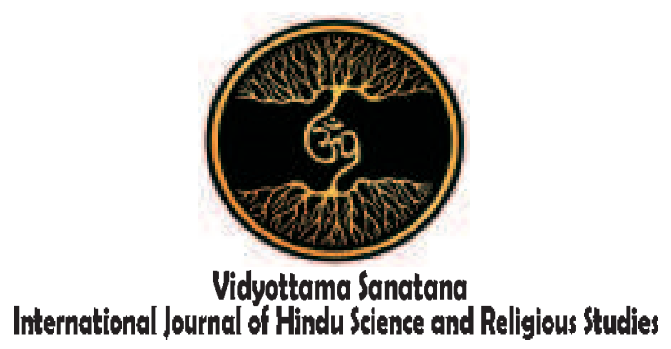

Vol. 1 No. 2 October 2017

\title{
The Process Of Transforming The Mahabharata Literary Work Written In The Old Javanese Into Geguritan Sarpayajnya And Geguritan Kicaka Written In The Balinese Language
}

\author{
By: \\ I Made Suastika, I Ketut Jirnaya, I Wayan Sukersa, \\ Luh Putu Puspawati \\ Faculty of Arts Udayana University
}

\begin{tabular}{|l|l|l|}
\hline Received: August 12, 2017 & Accepted: September 20, 2017 & Published: October 30, 2017 \\
\hline
\end{tabular}

\begin{abstract}
The story of the Pandawas and their wife in Wirata was used as the plot of the geguritanKicakawhich was initially transformed from Wirataparwa in the form of Parwa. The only episode which was transformed into geguritan written in the Balinese language is the one narrating when the Pandawas were in disguise for one year. In this episode the love story of their wife, Drupadi, who was disguised as Sairindriis also narrated. In this episode it is also narrated that the Chief Minister, Kicaka, would like to have her as his wife. However, the Chief Minister, Kicaka, was killed by Bima, who was disguised as Ballawa, meaning that the love story came to an end. From the language point of view, the episode telling that the Pandawas were in Wirata was transformed intoGeguritanKicaka written in the Balinese language. In addition, although the text was dynamically translated, many Old Javanese words are still used in the Balinese version.

Similarly, geguritan Sarpayajaya adopted the episode of Sarpayajnya of Adiparwa; however, the plot was modified again using thestrophes pangkur, dangdanggula, sinom and durma and was introduced using the Balinese language. It is narrated that King Parikesit was bitten and killed by a snake named Taksaka. Consequently, his son, Janamejaya, performed a ritual known as Sarpayajaya, causing all the snakes to die. From the cultural point of view, the text is recited as part of the performing art and the art of music 'magegitan' in Bali. The text Sarpayajayaisrecited as part of the cremation ceremony 'ngaben' known as mamutru.
\end{abstract}

Keywords: Mahabharata, Geguritan, Sarpayajnya, Kicaka 


\section{Introduction}

Transforming literary works written in one language into those written in the Balinese language is one of the ways of civilizing Bali. The process of transforming the literary works written in one language into the Balinese language is referred to as 'proses-pem-Balian' in the Indonesian language. The term 'pemBalian' is a Balinese local wisdom which is derived from the word Bali, meaning Bali. The prefix - pem and the suffix - an are added to the word Bali, meaning the world of Bali. As an illustration, in the fields of culture and literature, the external elements introduced to Bali are not accepted as we like, meaning that they are processed or deconstructed in such a way that they belong to Bali (Suastika, 1997).

As far as the Balinese literary works and culture are concerned, many things have been adopted from the Old Javanese culture, language and literature. They have been adjusted to the Balinese concept and way of thinking. As a result, newly-created literary works appear. In addition, the Old Javanese values become transformed into new forms. Pigeud (1967: 69) classifies the transformational process of the things adopted from the Old Javanese language into four. They are (1) the process of transforming the things related to ethics and religion into the Balinese language; (2) the process of transforming the things related to history and mythology into the Balinese language; (3) the process of transforming literary works, knowledge, arts, law, humanity, and so forth into the Balinese language.

The Mahabharataparwas (Mahabharata chapters) which were transformed into the Balinese language are referred to as Asta Dasa Parwa (18 parwas) in Bali. The parwa which was initially adopted from the Indian Mahabharata epic written in Sanskrit was rendered into the Old Javanese tradition before it was transformed into the Balinese language known as parikanor geguritan (philosophical verse). Parikan means adoption; it is a literary form written in the Balinese language; it can be adopted from the Old Javanese Mahabharata and other literary works. It is here that adoption takes place, which is different from translation. Adoption means adopting any literary work which was initially written in the Old Javanese language into the one written in the Balinese language; in this process the episodes are freely selected; some are tightly selected based on the source (babon). As an illustration, the Balinese literary works which were adopted from the Mahabharata text are parikan Salya, Bhagawan Domya, Sarpayajnya and Geguritan Kicaka.

In such literary works the change in form can be observed; the Mahabharata episode was transformed into geguritan/parikan written in the Balinese language. Some characters were adopted and changed; some episodes were added and some were reduced, depending on what was intended by the Balinese writers. The adopting process can be described in three models (code); they are the linguistic code, the literary code, the cultural or linguistic, literary and cultural aspects.

In relation to the process of transforming the Old Javanese literary works into the Balinese language, as the Balinese civilization, it is very important to explore comprehensively geguritan as a literary work adopted from the Mahabharata prose. The linguistic aspect, the literary aspect, and the cultural aspect should be investigated. The tradition of adopting the Old Javanese literary work Mahabharata Parwa into the Balinese literary work is a specific phenomenon which connects the literary tradition and what change is intended by the Balinese writers so that it can be easily understood and belong to its people. Therefore, the specific phenomenon in which the Mahabharata episode was transformed into geguritanneeds to be investigated. 


\section{Method}

The phenomenon of transforming the Mahabharata text written in the Old Balinese language into the one written in the Balinese language is the continuation of the process of what is known as Mang-Jawaken Byasamata (answering the value which the Mahabharata text contains) written in Sanskrit into the one written in the Old Javanese language known as Mahabharata. In Bali it is known as astadasaparwa (18 parwas/chapters) (Suastika, 2011). The essence of the literary work written by Byasa was adopted in such a way that new episodes were created. Many adopted Sanskrit words, phrases, sentences and couplets were freely translated into the Old Javanese language. In brief, on the one hand, many episodes were made to be shorter; on the other hand, many others were made to be longer, depending on what was desired by the writer in that era.

In this present study the data were obtained from texts and the field, meaning that the data were collected using the qualitative approach in which the researcher was the instrument. The result of analysis was presented informally, meaning that words (Indonesian language) were used to present the result of analysis in several chapters and sub-chapters.

\section{Result And Discussion}

\subsection{The Process of Transforming the Mahabharata Text into Geguritan Sarpayajnya written in the Balinese Language}

\subsubsection{The Process of Creating Geguritan Sarpayajnya}

The process of creating Geguritan Sarpayadnya which was taken from the Mahabharata story can be explained based on the information obtained by interviewing those who write and are fond of literary works 'nyastra'. In addition, they have the capability of writing and are rich in ideas. The desire they have strongly motivates them to present their ideas. If, for example, they want to implant characters, moral values, heroism, faithfulness, honesty, and the law of cause and effect 'karmaphala' (the karmic law), they do their best to search out a story with a similar theme which can be used as a model. Then they write their ideas in the form of literary works.

Geguritan Sarpayadnya leads the reader to the implicit theme "Literary Teaching and the Karmic Law". Although as a king, the character, Parikesit, could not do what he liked. As a king he should have been a model. He should not have draped the snake carcass around the neck of the Brahmin who had lived a holy life. Then the king Parikesit was killed by the snake Taksaka. Although he was a king, he could not avoid the karmic law.

\subsubsection{The Language Used in Geguritan Sarpayajnya}

The geguritan literary work is generally written in the Balinese language but the geguritan Sarpayajnya is not. Although it is mostly written in the Balinese language, many Old Javanese words are also used. The Balinese language is one of a great number of local languages in the archipelago. It has speech levels.

The Old Javanese language is one of the languages which developed in Java from the $9^{\text {th }}$ century to the $15^{\text {th }}$ century. During that era the Old Javanese words got mixed with almost fifty percent of the Sanskrit words especially adjectives and nouns. The Old JavaneseIndonesian dictionary written by P.J. Zoetmulder and S.O. Robson (1995) was used to identify that the words were the Old Javanese ones.

The following text exemplifies the Old Javanese words in Geguritan Sarpayajnya:

Raris keni kidange malahib, twara sidha mati kapisanan, Sang Prabhu doropon mangke, sahiringa manutug, ka tengah 
alase mangrañjing, hiringane pablesat, ada ngojog kawuh, ada mangungsi ngajanang, manglahadang tampak kidange malahib, twara bakat katudtudang.

(Bawa, 1996: 39).

The English version is as follows:

Then the antelope was shot with bow and arrow and ran, it did not die, the King was curious to know, all ran after it, entered the forest, his followers spread, some went to the west, some went to the north and followed the tracks of the running antelope, not found.

As mentioned above, the Balinese language has the Refined Variety "BahasaAlus" and the Rude Variety 'Bahasa Kasar'. The two varieties are used in the Geguritan Sarpayajnya. In Geguritan Sarpayajnya the Baliense language is mixed with the Old Javanese language. However, not many Old Javanese words are used, and the Balinese words used are the refined ones; only one rude word was found in the text.

\subsubsection{The Literary Aspect in Geguritan Sarpayajnya}

Among the islands in the Archipelago, Bali is the biggest collector of the classical or traditional texts. Initially, the classical texts were written on palm leaves 'lembaran-lembaran daun lontar'. Gradually, for the sake of different interests, such texts were written using the Balinese characters; then they were written using the Latin characters. There are still many texts written using the Balinese characters. The classical texts spread in Bali ; many are collected as personal collections. There are several private and governmental instititons that collect classical texts. One of the governmental instititons which collects the classical texts is Gedong Kirtya No. IV D/10.

Geguritan Sarpayajnya which was found and is still maintained in Bali is a Balinese literary work in the form of strophe 'pupuh'. This pupuh is bound to what is referred to as pada lingsa (regulation) or rythmic pattern (Sugriwa, 1978: 3). Pada lingsa includes what is referred to as guru gatra, namely the number of syllables in every line (carik), what is referred to as guru swara, namely the change in vowel (lingsa) in the last syllable of the sentence.

There are four pupuhs used in Geguritan Sarpayajnya; they are (1) Pupuh Dangdang Gula, (2) Pupuh Pangkur, (3) Pupuh Sinom, and (4) Pupuh Durma. Pupuh Dangdang Gula features the gentle, sweet and pleasant character. Therefore, Pupuh Dangdang Gula functions to express love, pleasant things, and teachings. Pupuh Pangkurfeatures the enthusiastic and resolute character; therefore, it functions to express seriousness, revenge, and advice. Pupuh Sinom features the friendly character; therefore, it functions to express beauty, happiness, young people's activities, and cheerfulness. Pupuh Durma features the rude, hard, angry and cruel character; therefore, it is used to express the things related to hostility, anger, war, chaos, and the like (Saputra, 1992: 21-29).

The binding literary regulations 'padalingsa' in every pupuh used in Geguritan Sarpayajnya can be seen in the following quotation. Couplet 24 of Pupuh Dangdang randomly quoted is made up of 10 (ten) lines with the following number of syllables and final voices as follows:
Kocapan Sang Prabu Pariksit, (10i)
sêrêng pisan tan kayun ngakúamâ, (18a)
meling ring kagunane, $(8 e)$
tan pakewêh ring kahyun, $(7 u)$
kasadyayang pisan naggêhin, (9i)
pangriúthan I Takúakâ, (7a)
tan hucapa sâmpun, (6u)
Bhagawan Samitthi tulak, (8a)
ka patapan makaron ring Sang Srênggi, (12i)
kocapan di Asttinâ. (7a)
(Bawa, 1996: 110) 
Pupuh Pangkur is made up of seven (7) lines; the $90^{\text {th }}$ couplet which was randomly quoted shows the number of syllables and the last voice as follows:

Hapine kabhînâ-bhînâ, (8a)
galak tuwi buka ngêrêsang athi, (11i)
kocapa nâgane sâmpun, (8u)
pacêbûr ñêburin kuódha, (7a)
nanging soroh gebogane pacêbûrbûr,
(12u)
len hada henu di jalan, (8a)
di hambarane ngimbangin. (8i)
(Bawa, 1996: 132)
That is how pupuh or Javanese poems are
in Geguritan Sarpayajnya as a converted
rary work.

\subsubsection{The Plot of Geguritan Sarpayajnya}

Parikesit, the Pandawa'sgrandson, was crowned as the king of Hastinapura. Once upon a time, he and his followers went hunting in the forest which belonged to the Hastinapura kingdom. An antelope was shot with bow and arrow; however, it did not die at once. It ran into the forest and was chased after. They asked Bhagawan Samiti, who was meditating and could not speak to anybody (monabratha) where the antelope ran. As he could not speak to anybody, he did not answer. The king Parikesit was so angry that the carcass of a grey snake was draped around Bhagawan Samiti's neck. Then the king returned to Hastinapura kingdom.

Srenggi, Bhagawan Samiti's son, and Kresna went to heaven for a walk. He cursed King Parikesit using his power that Naga Taksaka would bite the king.

Srenggi soon arrived at the location where his father was meditating and found that the putrid carcass of the snake still got draped around his neck. Srenggi informed his father that he had cursed the king. However, the father regretted that his son had cursed the king. The father said that his sondid not think about what would happen in the future. Furthermore, he was proud of the king Parikesit who controlled the area of Hastinapura, including the area where he was meditating. However, Srenggi had cursed the king and what he had cursed could not be nullified.

Naga Taksaka which was instructed by Srenggi to kill the King Parikesit found difficulties. Then it asked its relative which stayed at Saptapala a favor, which then transformed into a priest who offered the roseapple 'jambu'. Naga Taksaka transformed into a very tiny caterpillar hiding in the rose-apple. After the fruit was taken by the king, the tiny caterpillar changed into a giant snake and bit King Parikesit, causing him to be completely burned.

King Janamejaya, the son of King Parikesit, who heard the news, went to ask the priests to perform a ritual in which snakes were sacrificed (sarpayajnya). It was performed to kill Naga Taksaka, which had killed his father.

\subsubsection{The Cultural Aspect}

The classical literary work in Bali is closely related to the cultural life of its supporting community. The Balinese people still maintain, read and use the classical literary work in their daily life. As far as GeguritanSarpayajnya is concerned, if seen from the source, namely Adiparwa in general and the episode of Jaratkaru in particular, it is popular enough in Bali and is closely related to the memukur ritual, namely the ritual performed after the cremation ceremony 'ngaben' is performed. Such a parwais recited at night before the peak of the ritual is performed. The recitation of such a text is referred to as mamutru. The text is recited to propose that the soul of the person for whom the memukur ritual is performed will not like the soul of Jaratkaru, which was getting dry and hangingdown on a leaf of the bamboo tree. His/her relatives hope that the soul will not become separated from them and will be allowed to go to heaven.

Geguritan Sarpayajnya, as a classical 
Javanese poetry, also functions to amuse people after being busy with daily routines. It is stated to function as amusement as its couplets can be recited in different types of performing art such as arja, shadow play with leather puppet, and ballet.

Geguritan Sarpayajnya also contains the culture of being always introspective. One should always be quiet and patient as what should have been done by King Pariksit who did not have the answer from Bhagawan Samitri who was meditating and could not speak to anybody 'monabratha'. It also contains religious education and the karmic law 'hukum karmapala'. King Parikesit made a mistake when he was draping the carcass of a snake around Bhagawan Samitri's neck. Therefore, he underwent the same thing; he was killed by Naga Taksaka.

\subsection{The Process of Transforming the Mahabharata Text from Wirataparwa into Geguritan Kicaka}

The Mahabharata text which is made up of 18 parwas and, therefore, it is referred to as Astadaparwa is originally written in Sanskrit (India). Then it was transformed into the one written in the Old Javanese language during two main eras; during the Kediri and Majapahit eras and Gelgel-Klungkung era. During the Kediri and Majapahit eras, it was transformed into the one written in the Old Javanese language in Java and during the Gelgel-Klungkung era it was transformed in Bali (see Supomo Suryohudoyo, 1977; 1979; Suastika, 1997 and 1997; Pigeud, 1967.

Although the Mahabharata text was transformed into the one written in the Balinese language, the Javanese impact on the Balinese version can be clearly observed. The Old Javanese literary work transformed into the one written in the Balinese language was intended to make it widely understood in Bali. The form of the literary work and the language used were changed. In addition, the cultural aspect was also inserted. As an illustration, Adiparwawas written as the old Javanese literary work entitled KakawinPriksit, Kakawin Astikayana, Astikasraya, and Kakawin Pandawa wiwaha. The literary works entitled Kidung Sri Bhatara Kresna and Geguritan Sarpayajnya were created from Adiparwa. The Old Javanese literary work entitled Kakawin Wiratasraya and the Balinese literary work entitled Geguritan Kicaka were created from Wirataparwa.

The examples above illustrate the Old Javanese literary works which have been developed in Bali since a very long time ago. In fact, the Old Javanese literary work has become united with the Balinese literary work. Therefore, the literary work written in the Old Javanese language is also referred to as the Kawi literary work. The features of the literary works written in the Old Javanese language transformed into the literary works written in the Balinese language are as follows (Pigeud, 1967).

(1) Ethics, religion, and morality are the dominating genres;

(2) The mythology and history written in the Old Javanese language and Balinese language are the next dominating genres;

(3) There was also literature which was originally created in Bali;

(4) The literary works written in the Balinese language contain art values, legal values, knowledge values, humanity values and so forth.

In the end of the Klungkung era (the $19^{\text {th }}$ century), the Old Javanese literary works transformed into the ones written in the Balinese language can be more clearly characterized as follows.

(1) The new language style, namely the poetic pattern, appeared in Bali;

(2) The literary works created could be identified from the colophon; however, it was difficult to identify them chronologically; 
(3) The Balinese words distinctly featured the texts.

In this present study the process of transforming Wirataparwa written in the Old Javanese language into the classical poem GeguritanKicaka written in the Balinese language are discussed from the language aspect, literary aspect, and cultural aspect.

\subsubsection{The Process of Creating Geguritan Kicaka}

The writer of Geguritan Kicaka told that he was requested by a woman named Dayu Biang Sloka to write a song 'kidung' two or three times. She urged that the song be written in the Balinese language telling about how the Pandawas and their wife lived in Wirata kingdom.

The story was then continued with the episode of the events which caused them to be in disguise in the $13^{\text {th }}$ year. The geguritanwas written using pupuhDangdangand Pangkur from the beginning to the end. The pupuhDangdang totaled 31 and the pupuhPangkur totaled 77, and Dangdanggula totaled 13.

The writer used what is referred to as Wiratasarana in the episode when the Pandavas and their wife were in disguise. It was written in the common Balinese language variety; the story was fluent; almost no dialogues among the characters were mentioned; the episode was fluently narrated, from one scene to another until they were free from the punishment which caused them to be in disguise for one year. The story is interesting and the plots are easily understood by the readers.

\subsubsection{The Language Aspect}

The language used in Wirataparwa is the Old Javanese language (Mengjawaken Byasamata), namely the Old Javanese language variety used in the Javanese literary works from the $9^{\text {th }}$ century to the $15^{\text {th }}$ century. What Old Javanese variety was used is described in Zoetmulder (1957 and 1992). The following text exemplifies the language used in Wirataparwa.

Genep sapuluh lek lawas Sang Pandawa ring Wirataparwa, Sang Jadnya senitamolakaparek: Mahadewi Sudesna, sakarmaning paricarita pinakolah nira (15b).

The language styles used in the Wirataparwa text can be grouped into four:

1) the language style used to narrate parts of the story.

2) the language style used to describe the Sanskrit quotations.

3) the Old Javanese language used to explain the dialogues.

4) the short quotations in the forms of words and phrases.

The relationship between Wirataparwa and Geguritan Kicaka is that they use different languages. The former is written in the Old Javanese language and the latter is written in the Balinese language. It is clear that the Balinese language is used as a means of communication in the literary work. As an illustration, the Balinese version of the sentence Kerangan Ambek Sang Kicaka is translated into Sang Cacakauyeng paling, kenehibuk, and ibukjengah Sang Kicaka(Kicaka was seriously confused); the sentence Muwah dikahanan Dewi Sudesna, mwah mintakasih is translated into ketopangandikaIda, DyahSudesna, raja putri lewihegar Sang Cacaka and is retranslated into pareka ring DewiSudesnaujaraamelasih (that was what was said by Her Majesty, DyahSudesna, the Queen and younger sister of Kicaka, the chief minister).

\subsubsection{The Plot in Geguritan Kicaka}

It is narrated that the Wirata kingdom was governed by King Matsyapati whose wife was named DewiSudesna, the Kicaka's younger sister. The Pandawas were in disguise for one year and decided to choose the Wirata kingdom 
as their target. Dharmawangsa became a Brahmin named Dwijakangka teaching chess, Bima became a cook named Balawa, Arjuna became a hermaphrodite named Wrhatnala teaching dancing and singing. Nakula became a shepherd looking after horses and Sahadewa became a shepherd as well but he looked after cows. DewiDrupadi produced perfume and served the king's daughter and DewiSudesna.

After spending ten months at Wirata, something happened to Sairindri; Kicaka, the chief minister, became interested in her. However, she never did what was instructed and did not want to see Kicaka, the chief minister.

Kicaka always attempted to persuade Sairindi, but he always failed. One day the chief minister, Kacaka, intended to rape her but he could not and she could free herself. He kept chasing her until they were in front of DwijaKangka and Sang Balawa.

Balawa got angry and Sairindi was freed by Lord Surya from such a terrible situation. She informed the King on what had happened to her but he took no measures against Kicaka.

Being offended, Sairindri informed Balawa that she intended to take revenge against Kicaka, the chief minister, for what had been done.

\subsubsection{The Characters in Geguritan Kicaka}

It is narrated that the Pandawas were in disguise in Wirata kingdom for one year. They transformed themselves; they took off their royal accessories and wore casual clothes. As Kicaka attempted to persuade Sairindi, he was killed by Ballawa. His death was exposed to Trigarta (the kingdom which was under the Wirata kingdom). They affiliated with the Korawas. The war could not be avoided; King Matsya asked Kangka, Ballawa, Grantika, and Tantipala to fight against the troops of the Korawas and Trigarta and Wrhatnala was the coachman of the Rajaputra's cart.
On the journey Wrhanala changed his position; he led the war and Uttara became his coachman; he took the clothes kept in a cave; finally, the troop of the Korawaslost the war. King Matsya was happy to hear that his son won the war and would return to the palace. There was a misunderstanding among the fighters who were involved in and won the war. Then the Pandawas came to the palace and informed who they really were. The gold and properties which had been intended to be given to the Pandawas were refused. Only one which was accepted, namely Dewi Uttari to whom Abimanyu, Arjuna's son, was intended to be married.

\subsection{The Function Of Transforming The Literary Work Written In The Old Javanese Language Into The One Written In The Balinese Language}

\subsubsection{The Religious Function}

The religious function can be connected to the relationship between man and the Creator (Almighty God), the harmonious relationship between man and the environment and between man and his fellow-beings. God is the source of everything. He will come when one worships Him; man appreciates for everything He has done; His existence protects everybody and everything. There is the concept DewaRna which we should refer to when we appreciate God. God is the source of everything in the world; He has created the world and everything it contains; man, as one of the creatures He has created is obliged to worship and thank Him for protecting and giving prosperity to the world and everything it contains.

One of the attitudes which can be used to express that we glorify Him is that we should show our devotion to Him as what the world contains is His blessing. Water, forests, air, foods and everything needed for human life; in short, the nature and environment have been

Thh@OProcess Of Transforming The Mahabharata Literary Work Written In The Old Javanese Into Geguritan Sarpayajnya And Geguritan Kicaka ..... ～～I Made Suatika, dkk. 
created by Him. Human beings should be devoted to and respect Him physically and spiritually through different behaviors; we should say, do and think about the right things, and always worship Him through semedi, tapa, yoga (mediation) and by performing holy sacrificial rituals.

In Adiparwa it is explained that King Janamejaya, Parikesit's son, Abimayu's grandson, Arjuna's great grandson, instructed the priests to prepare a sacrificial ritual which would be led by a Brahmin. The ritual was performed to save the world as Naga Taksaka, the king of snakes, had bitten and killed King Parikesit. Therefore, the snakes that had been responsible for the Parikesit's death should be made to disappear through a magical ritual. As a result, they were all killed.

The Pandawas were born as the rewards from Gods for the magic formula charmed when Pandu was married to Kunti and Madri. The magic formula charmed by Kunti was heard by Lord Surya, leading to the birth of Karna; the magic formula addressed to Lord Darma by Kunti led to the birth of Yudistira; the magic formula addressed to Lord Bayu by Kunti (Lord of the wind) led to the birth of Bima (Wrkodara), the magic formula addressed to Lord Indra by Kunti led to the birth of Arjuna. And the magic formula charmed by Madri and addressed to God Agni led to the birth of the twins, Nakula and Sahadewa.

It is narrated that in Mosalaparwaattempts were made to annihilate the Yadu dynasty and Krsna and Baladewa dynasty in Dwarawati. One day Samba, Krsna's son, kidded a priest through a question whether his baby would be female or male. Feeling that he was kidded he told that a 'gada' (the Bima's weapon) would be born. It could be used in the war involving those who belonged to the Yadudynasty. It was also told that the gada could cause them to be annihilated. It was true that the gada which caused them to be annihilated had been born.
It is narrated in PrastanikaParwa that the Pandawas and Drupadi left the palace for Himalaya. They were not strong enough to continue the journey; consequently, they were dead one by one. The karmic law was responsible for this; they received the consequences of what they had done when they were alive on the journey to Mount Himalaya. The only Yudistirawho was free from the karmic law as he had always implemented good deeds 'darma' when he was alive. He was accompanied by a dog which turned out to be the transformation of Lord Darma.

In SwargarohanaParwa it was told that the Korawas could only stay happily for a short period of time in heaven before they were punished in hell as they had made a lot of sins when they were alive. Contrary to the Korawas, the Pandawas only felt miserable as the punishment they should receive for a very short period of time before they could stay in heaven eternally.

\subsubsection{The Social Function}

The function and social relationship in the form of the social interaction and the feeling of being close to one another in society based on the principle of loving and taking care of one another referred to as 'gotongroyong' (helping one another) can be more clearly observed from the following statements:

a) The earth is not only inhabited by human beings, they are also equipped with the nature, their God, and the nature both in the macro and micro levels;

b) Human beings depend on the life of their fellow-beings;

c) Human beings always do their best to have good relationship with their fellow-beings;

d) The relationship between human beings and their fellow-beings is always based on the principle of being equal.

From Adiparwa text it can be stated that the Pandawas and Korawas always interacted 
with their fellow-beings. The Pandawas, in particular, always lived peacefully from when they were children to when they were adults and old. When they were young, they loved one another, their parents, uncles, and mother. They still became united when they went to Mount Himalaya. In SwargarohanaParwa it was narrated that they still stayed happily and harmoniously in heaven.

In contrast, the Korawas, as a community of 100 siblings, did not show that they lived harmoniously; they tended to show conflicts especially with the Pandawas, leading them to the Bharatayudha war taking place in Kuruksetra.

In the war they were supported by their kings. As an illustration, the Pandawas were supported by King Krsna and King Salya. The Korawas were supported by Drona, Bisma, Karna and other kings. This indicates that one social community supported another as they had the same interests.

\subsubsection{The Educational Function}

In Adiparwa it was narrated that when the Pandawas and Korawas were children, they were taught how to use different weapons by different teachers. RsiDrona, for example, taught them to shoot with bow and arrow. To know how good they were at shooting using bow and arrow, a competition was held. From the competition the Pandawas seemed to be much better at shooting than the Korawas. Two of them were distinctly good at how to use weapons; they were Arjuna and Karna. They finally became hostile to each other as Karna supported the Korawas, while Arjuna never left the Pandawas.

In Wirataparwa it was narrated that being in disguise for one year after wandering in the forest for twelve years was a heavy education as this was not known by the Karawas and their cronies. If they had been known to be still alive, they would have been punished for another twelve years.
It was also narrated in Wirataparwa that their expertise in using weapons enabled the Pandawas to defeat the Korawas and their troop who came to invade the Wirata kingdom. Arjuna, who was disguised as Wrhatuala, took the weapons kept in the forest to fight against the Korawas. Utara, the son of King Wirata, who used to lead the war, became the coachman and then Arjuna led the war. The Korawas knew that Arjuna had several supernatural weapons and could defeat them.

In Udyogaparwa it was stated that Bisma was not successful in obtaining the rights of the Pandawas who lost in the gambling, and that Krsna failed to obtain the Indraprasta Palace for the Pandawas. He also failed to obtain their properties. Krsna, the personification of Lord Wisnu, stated that politically there were four ways of defeating enemies. They are negotiating in order to make agreements (sama), spreading conflicts or (bheda), bribing (dana), and violence (danda). After the first three had been taken, no agreements were made. Finally, the last alternative was chosen, namely violence. The Pandawas prepared themselves to go to Kurusetra to fight against the Korawas. The Pandawas intended to obtain their rights which had been carried away by the Korawas as, based on the agreement made with the Korawas, they and their wife had completed the punishment of being exiled in the forest for twelve years and being in disguise in the thirteenth year in order not to be known by the Korawas. If they had been identified, they would have been punished for another twelve years.

In Bhismaparta it was stated that the education which should be taken by a knight is what is known as darmaksatria. Initially, Arjuna was not interested in fighting against his teacher, father, nephews and cousins. He said nothing. However, at that time Krsna clearly and firmly stated that what a knight should do was keeping his enemies away. Arjuna should be responsible for what he was obliged to do 
as a knight. If he had not been responsible for what he was obliged to do as a knight, he would have been ridiculed.

At that time Krsna showed himself as Wisnu who controlled the world (triwikrama). Krsna was the past, is the present, and will be the future. He creates and maintains the world and carry human beings back to where they come from. He instructed Arjuna to take his weapon and to be involved in the war. Krsna would protect Arjuna and his brothers. He motivated Arjuna to go to Kuruksetra to fight against the Koraws. Finally, Arjuna became aware that as a knight he should fight against the enemies.

\subsubsection{The Aesthetic Function}

The aesthetic aspect can be seen from the beauty of the Astina Palace and the Indraprasta Palace, the beauty of the nature and forest, and the beauty of the river and mount. The journey made by a character through different types of nature, rivers, mounts and trees also shows the aesthetic function.

From the language aspect, the Old Javanese is tightly used based on the language rules. The journey made by characters was described as a beautiful one as they went through forests, mounts, water, sea and different plants.

The text is read using the tradition of prose reading in Bali and is referred to as palawakya. Such a tradition of prose reading is popular in Bali in general and in Karangasem in particular. The mabasan group (the group of people who recite geguritan) does not only recite the geguritan written in the Old Javanese language 'makakawin' but also read the text as they read prose. The long and short voices they make sound beautiful and the text reading is also followed by its Balinese dynamic translation.

In Bali geguritan is also recited through social media such as TV, HT, and HP when there are special events. The interactive activity beautifies the recitation.

In addition, many geguritan texts are recorded in the forms of cassette, $\mathrm{CD}$ and compact disk, allowing people to listen to the geguritan recitation where they like, at home, during a journey, on the car and so forth. The other versions of the geguritan recitation such as mageguntangan, mesantian, mapepaosan, and magegitan are also performed in almost every part of Bali.

\subsubsection{The Function of Cultural Conservation}

The Sanskrit Mahabharata epic containing heroism has been known in India since a very long time ago. It narrates the heroism involving the Pandawas and Korawas as the Kuru dynasty. Their historical journey shows that there were always conflicts between them resulting from their different interests. Contrary to the Pandawas who were always good, the Korawas were greedy for power.

The epic life in the Mahabharata text has attracted many people up to now. Even in Indonesia it was translated into Astadasaparwa (18 parwas) in the DyahBalitung era in Kediri in the $10^{\text {th }}$ century. However, among them only 8 parwas which have been inherited in Bali. The rest (10 parwas) were not discovered or they were not translated into the Old Javanese language in that era.

Now the text has been translated into the Balinese language in the form of geguritan. Even the text written in the Old Javanese language has been retranslated; in addition, new texts adopted from the Mahabharata text written in the Old Javanese language have also been created. What is unique is that the Subahaparwa text is not written in the Old Javanese language, but the Balinese writer has translatedgeguritan or kakawin into the Balinese language from the one written in the English language. 
The Mahabharata text was carved in the Perambanan Temple, Central Java and now it has been read in Bali as the text referred to as palawakya. The text written in the form of geguritanis recited in the form of the Balinese tembang (poem) referred to as magegitan, mageguritan, matembang, and mageguntangan. Now geguritanis popularly recited through the electronic media such as TV, radio and $\mathrm{HT}$ and the performing art.

\section{Conclusion}

Based on what was described above, several conclusions can be drawn as follows.

1. The Mahabharata text, starting from Adiparwa to Swargarohanaparwa, written in the Old Javanese language has been transformed into ge guritan written in the Balinese language.

2. The Adiparwa has been transformed into geguritanSarpayajnya, Bhismaparwa has been transformed into geguritanSalya, and Wiraparwa has been transformed into geguritanKicaka.

3. The process of transforming Adiparwa into geguritanSarpayajnya written in the Balinese language can be explored from the language aspect, the literary aspect, and the cultural aspect. The process of transforming Bhismaparwa (salyaparwa) into the geguritanSalya written in the Balinese language can also be explored from the language aspect, literary aspect and cultural aspect. So can the process of transforming Wirataparwa into geguritan Kicaka written in the Balinese language.

4. The transformation of the Mahabharata text into geguritan written in the Balinese language has educational, aesthetic, social and cultural conservation functions.

\section{References}

Geriya, I Wayan. 2008. Transsformasi Kebudayaan Bali Memasuki Abad XXI. Surabaya: Paramita.

Sudarsana, I. K. (2017). Interpretation Meaning of Ngaben for Krama Dadia Arya Kubontubuh Tirtha Sari Ulakan Village Karangasem District (Hindu Religious Education Perspective). Vidyottama Sanatana: International Journal of Hindu Science and Religious Studies, 1(1), 1-13.

Sudarsana, I. K. (2016, October). The Importance Of Morals Teaching In Shaping The Students' Characters In School. In Dharma Acarya Faculty International Seminar (DAFIS) (No. ISBN : 978-602-71567-5-3, pp. 367376). Dharma Acarya Faculty Hindu Dharma State Institute (IHDN) Denpasar in Association with Jayapangus Press.

Wiana, I Ketut. 2002. Memelihara Tradisi Weda, PT offset BPDenpasar. 